\title{
Oncolytic herpes simplex virus and immunotherapy
}

\author{
Wenqing $\mathrm{Ma}$, Hongbin $\mathrm{He}^{*}$ and Hongmei Wang
}

\begin{abstract}
Background: Oncolytic viruses have been proposed to be employed as a potential treatment of cancer. Well targeted, they will serve the purpose of cracking tumor cells without causing damage to normal cells. In this category of oncolytic viral drugs human pathogens herpes simplex virus (HSV) is especially suitable for the cause. Although most viral infection causes antiviral reaction in the host, HSV has multiple mechanisms to evade those responses. Powerful anti-tumor effect can thus be achieved via genetic manipulation of the HSV genes involved in this evading mechanism, namely deletions or mutations that adapt its function towards a tumor microenvironment. Currently, oncolytic HSV (oHSV) is widely use in clinical; moreover, there's hope that its curative effect will be further enhanced through the combination of oHSV with both traditional and emerging therapeutics.

Results: In this review, we provide a summary of the HSV host antiviral response evasion mechanism, HSV expresses immune evasion genes such as ICP34.5, ICPO, Us3, which are involved in inducing and activating host responses, so that the virus can evade the immune system and establish effective long-term latent infection; we outlined details of the OHSV strains generated by removing genes critical to viral replication such as ICP34.5, ICPO, and inserting therapeutic genes such as LacZ, granulocyte macrophage colony-stimulating factor (GM-CSF); security and limitation of some oHSV such G207, 1716, OncoVEX, NV1020, HF10, G47 in clinical application; and the achievements of oHSV combined with immunotherapy and chemotherapy.

Conclusion: We reviewed the immunotherapy mechanism of the oHSV and provided a series of cases. We also pointed out that an in-depth study of the application of oHSV in cancer treatment will potentially benefits cancer patients more.
\end{abstract}

Keywords: Oncolytic herpes simplex virus, Cancer, Immune escape, Genetically engineered, Oncolytic viral therapy

\section{Review}

\section{Introduction}

For the past few years,despite constant new attempts finding phenomenal cancer treatments, chemotherapy, radiation and targeted drugs therapy are still the main therapeutic method in clinical practice. However, many problems remain in these methods, such as incompleteness, severe side effects, easy development of drug resistance, and lack of control in tumor recurrence and metastasis, etc., all of which lead to unsatisfactory result in treating tumor. The shortcomings of these major therapies call for new strategies in the field of cancer [1].

\footnotetext{
*Correspondence: hongbinhe@sdnu.edu.cn; hongmeiwang@sdnu.edu.cn Ruminant Diseases Research Center, Shandong Provincial Key Laboratory of Animal Resistance Biology, College of Life Sciences, Shandong Normal University, Jinan 250014, China
}

The Oncolytic virus is a subtype of a lytic virus that selectively replicates and kills cancer cells and spreads within the tumor without damaging normal tissue. The activities of oncolytic virus reflect the basic biological principles of the virus and the interaction of host-virus in the fight between pathogenesis and the immune system [2].

HSV, a member of the alpha-herpesviruses subfamily, shares many similarities with pseudorabies virus, varicella-zoster virus and infectious bovine rhinotracheitis virus [3]. The virus contains double stranded DNA genomes of at least $120 \mathrm{~kb}$, encoding for 70 or more genes. At present, lysotype HSV is the first virus to be developed into a recombinant oncolytic viral therapeutic vector, and the first oncolytic virus to fight cancer. As a cytolytic virus HSV possesses the following advantages: (1) HSV replicate quickly in cells and has capability to

(c) The Author(s). 2018 Open Access This article is distributed under the terms of the Creative Commons Attribution 4.0 International License (http://creativecommons.org/licenses/by/4.0/), which permits unrestricted use, distribution, and 
infect multiple types of cancer cells; (2) HSV has a large genome, which can be easily modified and be inserted with multiple additional transgenes [4, 5]; (3) HSV can be prevented with antiviral drugs when the dose start to impose threat to the patients' lives [6-8]; (4) Modifying the glycoprotein of HSV can improve the targeting of tumor cells [9].

As efficient OVs, HSV has some ability to escape the host's immune response including: To complement and incapacitate immunoglobulins via viral glycoproteins; to inhibit the production of cytokine/chemokine from infected cells [10]; to block the antigen presenting cells' (APCs) maturation [11]; to evade host immunological surveillance via negative-regulation of the expression of MHC class I [12] and to inhibit the apoptosis and cell death induced by cytotoxic T lymphocyte(TL) [13]. For deletion or mutation of those genes that were involved in HSV's escape through its host' immune defense will prohibit its replication in normal cells. Tumor microenvironment is often in an immunosuppressive state, which may allow the virus' entry and replication, which in turns eventually leads to the dissolution and death of tumor cells (Fig. 1). oHSV can also reverse the immune suppression of tumor microenvironment, enhance tumor immunogenicity, promote the infiltration of inflammatory cells, and play an effective anti-tumor effect.

This review elaborates on how the HSV surmounts the anti-viral defense mechanism of the host; the oHSVs' involvements in deletion or modification of viral gene and the clinical development of oHSV. A better understanding of the complex pattern of the interaction between HSV and host, and combination with current clinical oHSV is essential to the refinements the strategy of oHSV, thus to improve the

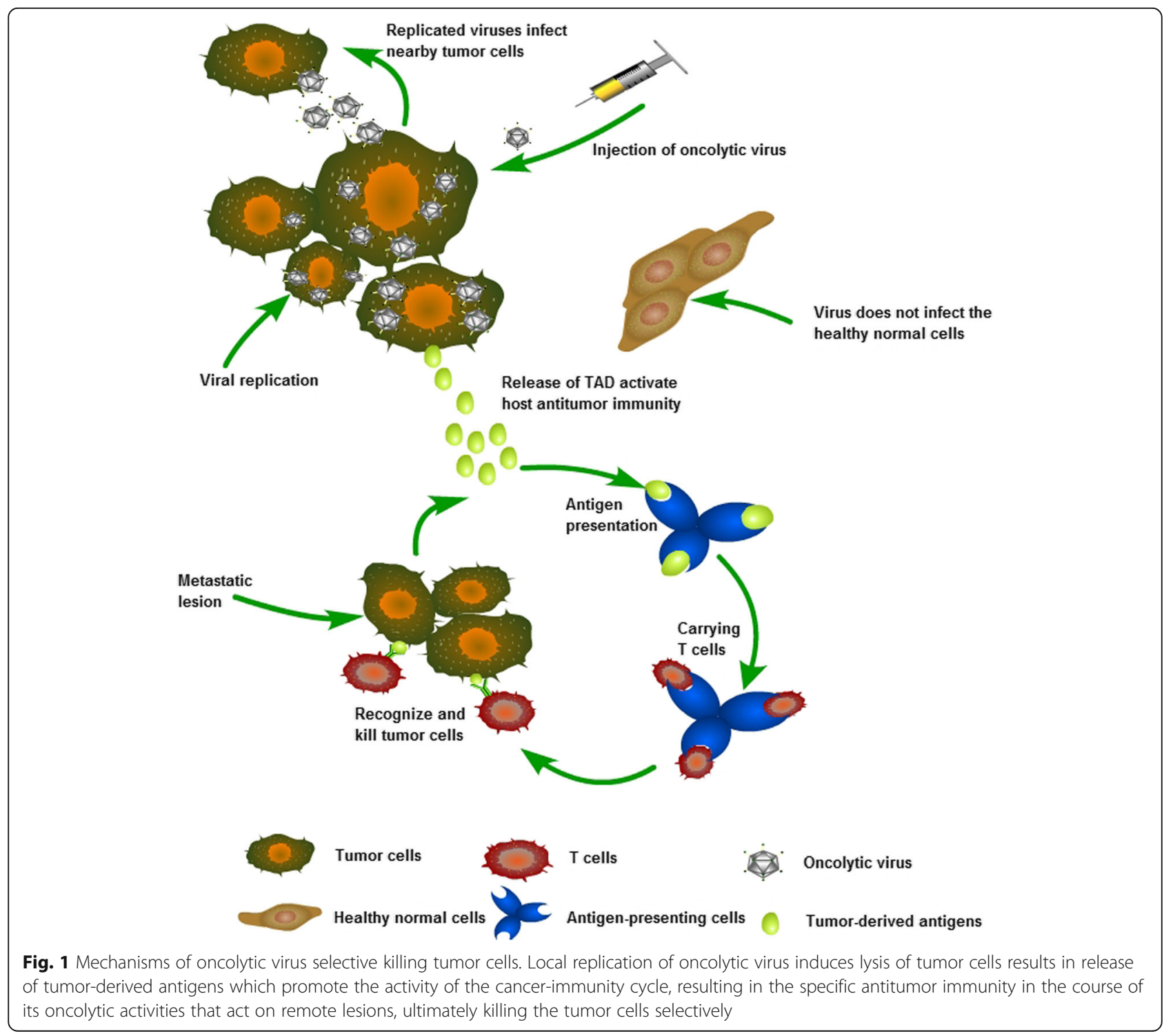


therapeutic effects and to comprehend the oHSV immune imperfection.

\section{The mechanism of HSV confronted the host immune response}

The infection of HSV causes to a cascade reaction of host anti-viral immunity responses. As a successful pathogen, HSV expresses proteins which are involved in inducing and activating host responses, so that the virus can escape from the immune system and set up effective long-term latent infection. HSV has various mechanisms to escape the host reactions (Fig. 2):

\section{Envelope glycoprotein}

The envelope glycoproteins of HSV can escape humoral immunity mechanisms, such as Glycoprotein $\mathrm{C}$ binding and inactivating properdin and complement protein $\mathrm{C} 3 \mathrm{~b}, \mathrm{C} 5$ to protect the virus from virus neutralization mediated by complement induced via natural IgM and antibody-independent complement neutralization [14, 15]. gE and gI encode Fc receptors, which can attach to
IgG [16]. This binding inactivation of complement mediated via antibody and cytotoxicity of antibody dependence conduce pathogenicity [17]. gD inhibit the expression of CD112, which binds to the natural killer (NK) cells excitating receptors DNAX accessory molecule 1 (DNAM1), leading to a noneffective binding and lysis to HSV-infected or gD-transfected cells via NK [18]. HSV inhibits the expression of CD1d, surface molecules of APCs, and thus reduces NKT cells stimulate [19].

\section{Immune evasion genes}

A series of genes encoded via HSV escape the host antiviral immune monitoring mechanism $[10,20]$. In cancer cells, some of these pathways are flawed [21]. Interferon (IFN) 1 signaling pathway, crucial for antiviral innate immunity [22], relates to genes that are involved in pathways such as the TLR signaling pathway: Us3 inhibit the signal transmission of TLR3 and TLR2 to TRAF6 [23], deubiquitinase for UL36 down-regulate the expression of TRAF3 [20], ICP0 inhibite the expression of P50 and

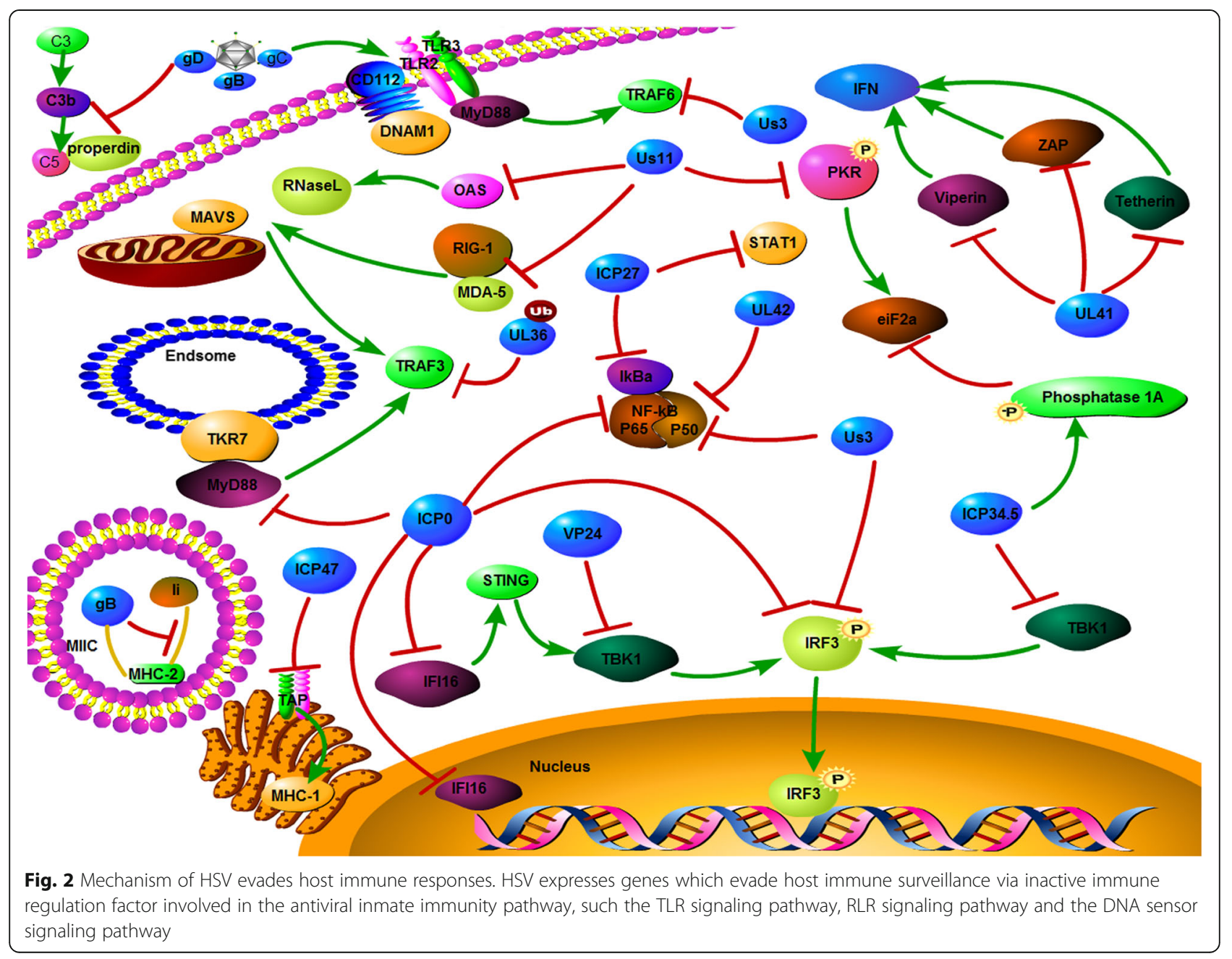


P65, the subunits of MyD88 and NF-kB [24], UL42 and Us3 inhibit the process of nuclear translocation via

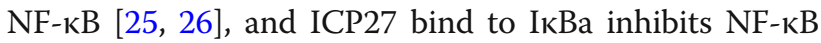
[27]. In the RLR signaling pathway: the Us11 can combine with RIG-I and MDA-5, thus inhibits the integration with MAVS [28, 29]. ICP34.5 inhibit the phosphorylation of IRF3 by binding TBK1 [30], US3 inhibit production of IFN- $\beta$ via hyperphosphorylation of IFN regulatory factor 3 (IRF3) [31], ICP0 prevents IRF3 sustained activation, thus inhibiting translocation from the nucleus to cytoplasm [32]. Influence of the DNA sensor signaling pathway is also present: IFI16, involved in sensing pathogen DNA and initiating signaling pathways, inhibits via ICP0 in the nucleus [33]. In addition, IFN-stimulated genes, UL41 the virion host shutoff protein (Vhs), inhibits viperin, ZAP, and tetherin via degraded mRNA [20, 34], Us11 inhibits OAS [35] and protein kinase R (PKR) [36]. Eukaryotic Initiation Factor 2 (eIF2a) phosphorylated via PKR, shuts down the synthesis of protein. ICP27 blocks the phosphorylation and activation of STAT-1 [37]. Due to the defection of cancer cells in IFN signaling [38], deletion or mutation in these immune evasion genes such as ICP34.5, ICP0, Us3 in oHSV will avail ourselves of a cancer therapy [21].

\section{Block dendritic cells function}

Dendritic cells (DCs) are polymorphisms and heterogeneous antigen presenting cells, it has vital function for the recognition of pathogens at the site of infection and the initiation of protective HSV-specific T cells [39]. HSV has numerous mechanisms to inhibit DCs function [11]. ICP34.5 binds to TBK1 and IKK $\alpha / \beta$, impeding the maturation of DCs and inhibits autophagy by interfering with antigen presentation [40, 41]. ICP0 induces CD83 degradation as a DCs maturation marker, leading to a decrease in T cell stimulation [42] ICP47 blocks transporter associated with antigen presentation (TAP), inhibits MHC I-peptide presentation, and thus leads to a mediated by MHC I to CD8+ T-cells to escapes immunological surveillance in host cells without antigen presentation. Pourchet A et al. showed that oHSV express UL49.5 from BHV-1 has a high efficacy treating cancer models, which is rely on CD8+ $\mathrm{T}$ cells [43]. gB binds to HLA-DM and HLA-DR, which yields a negtive-regulation of MHC II pathway in CD4+ T cells [44]. ICP34.5 and UL41 interfere with antigen presentation of CD4+ T cells via down-regulated MHC II accumulation on the surface of glioblastoma cells [45].

$\mathrm{T}$ cells are also influenced via HSV infection. Firstly Us3 inhibits LAT, which is the linker activating T cells, and in turns blocks TCR signaling [24]. Secondly oHSV infection has an impact on the pathway in T cells, such as inhibiting NF- $\mathrm{kB}$, activating STAT3, JNK and MAPK p38 pathways, and suppressing the pro-inflammatory cytokines synthesis, such as IL-2, TNF-a and increasing IL-10 synthesis [46].

\section{Inhibition of autophagy}

Autophagy is an important cellular degradative pathway [47], which exerts on cellular pathogens like oHSV with a process similar to the MHC I and II presented in APCs [48]. ICP34.5 targets Beclin1 and interacts with PPP1CA, blocking the formation of autophagosome [49-51]. HSV induced EIF2AK2 activation down-regulates the Beclin1mediated autophagy [49, 51]. In additional, ICP34.5 directly inhibits TBK1, which can regulated the phosphorylation of autophagic receptors SQSTM1/p62 and optineurin (OPTN) to mediate substances recruitment into phagophores for degradation [52]. Us11 interacts with EIF2AK2, inhibiting the phosphorylation of EIF2S1, mediated via EIF2AK2, to block autophagy [53].

\section{Inhibition of apoptosis}

Apoptosis, the programmed cell death, can clear up the infected cells. HSV encoding anti-apoptotic virulence factors to suppress apoptosis then gives the virus enough time to replicate after infection [13, 54]. After HSV infection, some genes like ICP6, Us3, gD and Us5 (gJ) play role in the suppression of cells apoptosis. Us3 suppresses the expression of cytochrome $\mathrm{c}$ and the activation of caspase-3 [54], Us3 protein kinase activates the proapoptotic proteins Bad and Bid [55]. Us5 (gJ) antagonizes Fas/UV-induced apoptosis and weakens the granzyme B-mediated pathways of CTL-induced apoptosis [56]. Compared to gJ, Us6 (gD) blocks apoptosis at different stages of the viral life cycle. Necroptosis, another programmed cell death, which absence of caspases. ICP6 suppress apoptosis by blocking caspase 8 mediated via TNF- $\alpha$ and Fas ligand [57], also blocking necroptosis induced by TNF via inhibits the binding of RIP1 and RIP3 [58]. However, ICP6 had the reverse effect, in mice [13, 59].

The interactions of these host viruses are crucial to harmonize the OV activity, regulate the OVs anti-viral immune responses, and inducing anti-tumor immunity.

\section{Genetically engineered oHSV}

The key to eradicate tumors in this new therapy is to improve the precision when targeting oHSV for tumors, and enhance the suppression. Genetic engineering can affect many aspects of how viruses' work. To enhance tumor selectivity by removing key genes in healthy cells that replicate with the virus. Table 1 summarizes the modified viral genes in oHSV and the functions of viral proteins encoded by these genes.

Dlsptk, the first type 1 herpes simplex virus mutants, includes a mutation within the UL23 gene that encodes the thymidine kinase (TK) gene. Dlsptk can inhibit the growth of glioma in nude rat brain [60,61]. Nevertheless, high 
Table 1 Immune evasion genes of HSV

\begin{tabular}{|c|c|c|c|}
\hline Gene & Protein & Function & oHSV name \\
\hline UL27 & gB & $\begin{array}{l}\text { Part of initial attachment of the virus to the cell by binding to heparan sulfate. With } \\
\mathrm{gH} / \mathrm{gL} \text {, enables fusion of the envelope with the cell membrane. Down-regulation of } \\
\mathrm{MHC} \text { II processing pathway in CD4+ cells. }\end{array}$ & R5141; KNE \\
\hline UL44 & $g C$ & $\begin{array}{l}\text { Forms the initial attachment of the virus to the cell by binding to heparan sulfate. } \\
\text { Inactivates serum complement proteins. }\end{array}$ & R5141 \\
\hline US6 & $\mathrm{gD}$ & $\begin{array}{l}\text { Binds to HVeM and/or nectin-1, leading to a conformation change that initiates fusion. } \\
\text { Down-regulates NK receptor ligand and NK-mediated lysis; inhibition of apoptosis. }\end{array}$ & R5141; R-LM249; HSV1716EGFR; KNE \\
\hline RL1 & ICP34.5 & $\begin{array}{l}\text { Major neurovirulence gene. Suppression of PKR/elF-2a signaling pathway and IFN- } \\
\text { induced anti-viral mechanisms; Inhibits DC maturation and antigen. Presentation; } \\
\text { Blocks MHC class II accumulation on the cell surface; Binds to Beclin-1, inhibiting } \\
\text { autophagy. }\end{array}$ & $\begin{array}{l}\text { HSV1716; R3616; OncoVex }{ }^{\text {GMCSF}} ; \text { G47; } \\
\Delta \text { G207; DM33; }\end{array}$ \\
\hline RL2 & ICPO & $\begin{array}{l}\text { Blocks NF-kB-mediated transcription of immunomodulatory cytokines, and IRF3- } \\
\text { induced and IRF7-induced anti-viral signaling pathways; inhibits IRF3 translocation to } \\
\text { the nucleus; inhibits IFI16; degradation of mature DC marker (CD83). Involved in } \\
\text { transcription of viral genes. Has ubiquitin ligase activity. Inhibits interferon response. } \\
\text { Alters the cellular environment to promote viral replication. }\end{array}$ & R7020 (NV1020); \\
\hline UL39 & ICP6 & $\begin{array}{l}\text { Major subunit of ribonucleotide reductase. Blocks TNF-a-mediated and Fas ligand- } \\
\text { mediated apoptosis through interacting with caspase } 8 \text { and necroptosis. }\end{array}$ & hrR3; G47 \\
\hline UL54 & ICP27 & $\begin{array}{l}\text { Inhibits cellular mRNA splicing. Recruits necessary proteins involved in viral } \\
\text { transcription and translation. Activates cellular pathways to promote viral replication. } \\
\text { Blocks NF-kB and IRF3 signaling pathways; blocks STAT1 activation and its translocation } \\
\text { to the nucleus. }\end{array}$ & HF10 \\
\hline US12 & ICP47 & Down-regulates MHC class I by inhibiting TAP. & G47D; OncoVex ${ }^{G M C S F}$ \\
\hline US11 & US11 & $\begin{array}{l}\text { Binds to and is phosphorylated by PKR, preventing cellular inhibition of protein } \\
\text { synthesis and autophagy; blocks OAS. }\end{array}$ & $\mathrm{G} 47 \Delta$ \\
\hline US3 & US3 & $\begin{array}{l}\text { Inhibits NF-KB activation and reduces cytokine expression, such as IL-8; inhibits induction } \\
\text { of apoptosis; hyperphosphorylates IRF3 to block activation of RLR signaling pathway. }\end{array}$ & R7041 \\
\hline UL48 & VP16 & $\begin{array}{l}\text { Initiates transcription of immediate early genes. Inhibits NF-kB activation and blocks } \\
\text { IRF3 pathway and IFN- } \beta \text { production. }\end{array}$ & KM100 \\
\hline
\end{tabular}

doses of Dlsptk can cause fatal encephalitis. For this reason, it is necessary to look for other engineered herpes mutants with low toxicity [62].

HrR3, the recombinant HSV-1, insert a LacZ in HSV-1 UL39 (encode ICP6), alternatively replicates in cancer cells, which has remarkable anticancer activity $[63,64]$.

HSV1716 was isolated from HSV-1 (17+) strain, deletes two copies of the main neurotoxic determinant generepeat RL1, which encodes neurotoxic determinant ICP34.5). PKR phosphorylates eIF2a, thus inhibits protein translation and induces cell apoptosis and kills the virus. ICP34.5 mediated dephosphorylation of eIF2a prevent cell apoptosis and protect the survival and reproduction of virus [65]. 1716 targets cancer cells that uncontrollable protein synthesis [66].

R3616, isolated from HSV-1 (F) strain, deletes the two replicas of ICP34.5 genes. R3616 can effectively induce host anti-tumor immune response by inducing a series of immune cells [67]. Kanzaki et al. showed that R3616 infects tumor antigen-specific lymphocytes; this not only effect on primary tumors, but also regulates multiple metastases [68].

NV1020 is an attenuated HSV that contains a diploid gene (RL1, RL2 and s1), with UL56 in the genome deleted [69]. Moreover, NV1020 attenuated via delete the TK gene and the UL24 genes promoter, and then inserts an exogenous copy of TK gene. These changes allow NV1020 highly attenuated and only proliferates in tumor cells.

G207, the first oHSV to be tested in clinical trials, deletes the ICP34.5 and inserted the LacZ gene, so the virus can selectively spread in tumor cells [70]. The deletion mutants ICP34.5 induced the down-regulate of late viral genes including US11 via PKR [9]. G207 can induce systemic anti-tumor immunity, which is related to the activation of cytotoxic T lymphocytes [8].

G47 $\Delta$ derived from G207, contain two of the mutations in the RL1 and ICP47 genes, and insert the LacZ in ICP6 gene (coding ribonucleic acid reductase large subunit) area cause its inactivation. Inactivation of ICP6 then induces the oHSV's only replicate in proliferating cells. Furthermore, the ICP47 mutation can effectively activate the host's anti-tumor immune response via enhanced MHC-I expression [71]. Due to the three remoulds in the genome, G47 $\Delta$ may be less toxic and more secure than G207 and T-Vec.

DM33 includes deletions of ICP34.5 and LAT gene. Unlike Dlsptk, DM33 was isolated from the McKrae 
strain, which promotes viral growth and kills cancer cells [72, 73].

HF10, remove the $3.9 \mathrm{~kb}$ connection point between the right end of UL and UL/IRL, which caused the loss expression of UL56, and reproduction of UL53 (gK), UL54 (ICP27) and UL55 [9]. HF10 enhances angiogenesis and induces acytotoxic $\mathrm{T}$ lymphocytes anti-tumor response [62].

Oncovex ${ }^{\text {GM-CSF }}$, ICP34.5 and ICP47 genes in HSV-1 were strike out, and the integration of human GM-CSF was step in the ICP34.5 site. A series of cytokines such as IL12, GM-CSF, IFN- $\alpha$ and tumor necrosis factor (TNF- $\alpha$ ) used with oHSV can modify and enhance the anti-tumor immunity. The GM-CSF shows the most effective results. TNF- $\alpha$, IL-12 and IFN- $\alpha$ preclinical cancer studies have also show promising contributions [74, 75]. Oncovex ${ }^{\mathrm{GM}-\mathrm{CSF}}$ enhanced antigen-specific $\mathrm{T}$ cell response and decreased inhibitory $\mathrm{CD} 4+$ regulation of $\mathrm{T}$ cell expression, with a specific antitumor effects achieved in CD8+ T cells [76].

\section{Clinical development and limitations of oHSV}

Oncolytic viruses have assessment for treatment of a series of mlignation tumors. The first clinical trials of engineered virus was conducted in the 1990s [77]. Several different oHSV have been or will be tested worldwide for various cancers; some have been developed to phase II/III trials, such as G207, 1716, OncoVEX, NV1020, HF10, G47 $\Delta$ (Table 2) [78].

Initially, oHSVs lay emphasis on security vectors, which included the deletes ICP34.5 gene, such as HSV1716. HSV1716 was first demonstrated to be safe and toxic in patients with pleomorphic glioblastoma and intersex astrocytoma [79]. The results showed that HSV1716 had good tolerance and no adverse reactions occurred after high dose of $1 \times 10^{5}$ PFU treatment. HSV1716 has been used in the treatment of glioma and oral squamous cell carcinoma [80-82].

Then strains with additional multiple deletions or mutations in case of the reversion of wild type virus, like the G207 [83], became the first oHSVs used in clinical trial. G207 has been used for recurrent malignant glioma in phase I studies, untoward effect have been moderated to slight fever and local erythema/inflammation reactions at the sites of injection [84].

G47 $\Delta$ enhances the anti-tumor efficacy while retaining the safety characteristics of G207 [85-87]. G47 $\Delta$ showed efficacy in all solid tumor models tested in vivo, such as hepatocellular carcinoma [88], schwannoma [89], prostate cancer [87, 90, 91], nasopharyngeal carcinoma [71], glioma, thyroid carcinoma [92], colorectal cancer, breast cancer [93] and malignant peripheral nerve sheath tumor. G47 $\Delta$ has the ability to killing cancer stem cells [94]. At present, G47 $\Delta$ is the only third generation oHSVs tested on humans [85].

NV1020 safety and efficacy have been demonstrated in some cancer diseases, such as colon carcinoma, pleural cancer, bladder cancer and pancreatic cancer [95-98]. Kemeny $\mathrm{N}$ et.al investigated the safety and tolerance of NV1020 in liver metastasis of colorectal cancer in a phase I clinical trial [99]. NV1020 was also tested for liver metastasis from colorectal cancer in phase II trials. The results show that NV1020 is safe and effective in anti-tumor therapy [100]. In phase III trials, NV1020 was used in combination with cytotoxic and targeted drugs [62].

Table 2 oHSVs of genetic engineering and its clinical application

\begin{tabular}{|c|c|c|c|}
\hline oHSV name & Genetic modification & Descrption & Clinical application \\
\hline Dlsptk & $\mathrm{TK}^{-}(\mathrm{UL23})$ & Internal deletion within UL23 & Malignant human gliomas \\
\hline hrR3 & UL39 & Insertion of LacZ (encodes $\beta$-galactosidase) in UL39 & Pancreatic cancer; colon carcinoma; liver cancers \\
\hline HSV1716 & ICP34.5 & Deletion in both copies of ICP34.5 & $\begin{array}{l}\text { Glioblastoma multiforme; anaplastic astrocytoma; oral } \\
\text { squamous cell carcinoma }\end{array}$ \\
\hline R3616 & ICP34.5 & Deletion of two copies of ICP34.5 & Pancreatic cancer; colon carcinoma \\
\hline G207 & ICP34.5 & $\begin{array}{l}\text { Deletions of two copies of the ICP34.5; insertion of an } \\
\text { Escherichia coli LacZ }\end{array}$ & $\begin{array}{l}\text { Prostate adenocarcinoma; glioblastoma; hepatocellular } \\
\text { carcinoma; colorectal cancer }\end{array}$ \\
\hline $\begin{array}{l}\text { R7020 } \\
(\mathrm{NV} 1020)\end{array}$ & $\begin{array}{l}\text { UL23, UL55, UL56, } \\
\text { RL1, RL2, RS1 }\end{array}$ & $\begin{array}{l}\text { Deletion of UL23, as well as the region encoding UL55, } \\
\text { UL56, and one copy of RL1, RL2, and RS1 (though not } \\
\text { the RS1 promoter) }\end{array}$ & $\begin{array}{l}\text { Pancreatic cancer; colon carcinoma; bladder cancer; } \\
\text { pleural cancer }\end{array}$ \\
\hline $\mathrm{G} 47 \Delta$ & $\begin{array}{l}\text { RL1, UL39, US11, } \\
\text { US12 }\end{array}$ & $\begin{array}{l}\text { Deletion of the overlapping US11 promoter/US12 } \\
\text { region, putting expression of the normally late US11 } \\
\text { gene under the immediate early US12 promoter }\end{array}$ & $\begin{array}{l}\text { Prostate adenocarcinoma; glioblastoma; rectal cancer; } \\
\text { nasopharyngeal carcinoma; breast cancer }\end{array}$ \\
\hline OncoVex ${ }^{G M-C S F}$ & ICP34.5 and ICP47 & $\begin{array}{l}\text { Deletion of two copies of ICP34.5 gene and the viral } \\
\text { ICP47 genes; insertion of GM-CSF }\end{array}$ & $\begin{array}{l}\text { Breast cancer; head and neck cancer; gastrointestinal } \\
\text { cancers; malignant melanoma }\end{array}$ \\
\hline HF10 & $\begin{array}{l}\text { UL53, UL54, UL55, } \\
\text { UL56 }\end{array}$ & $\begin{array}{l}\text { Spontaneous deletion of UL56 as well as duplication of } \\
\text { UL53, UL54, and UL55 }\end{array}$ & Breast cancer; malignant melanoma; pancreatic cancer \\
\hline DM33 & ICP34.5 & Deletions of $\gamma$-34.5 and LAT gene & Human gliomas and glioma cell line \\
\hline
\end{tabular}


Oncovex $^{\text {GM-CSF }}$ is the first type of oncolytic virus. After genetic engineering, oncogm-csf can selectively replicate in tumor cells, directly inject into the lesion, express GM-CSF, and enhance systemic anti-tumor immune response $[68,101]$. GM-CSF insertion can promote complementary anti-tumor immune response by recruiting APCs [102]. After intratumoral injection of

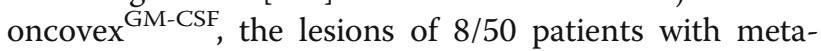
static malignant melanoma disappeared completely [103]. The safety of an oncovex ${ }^{\mathrm{GM}-\mathrm{CSF}}$ has been determined in phase I studies [104]. Direct injection of oncovex $^{\text {GM-CSF }}$ into melanoma lesions yielded an objective response rate of $28 \%$ in phase II clinical trials. Phase III clinical trials are ongoing [62].

However, oncolytic viruses all have the peculiarity of parental viruses and have some defects. Although HSV-1 is transmitted between cells and does not cause viremia, the most effective method for oncolytic HSV-1 is intracellular administration, which may not be suitable for intravenous infusion [105]. Because there are some drawbacks in intravenous administration, circulating antibodies may reduce the efficacy [106]. Viremia naturally causes viruses to be easily neutralized by antibodies; so the antineoplastic effect of intravenous administration of such viruses is limited in patients who have been treated or vaccinated. Clinical trials using oncolytic measles virus in the treatment of multiple myeloma fully demonstrated the adverse effects of circulating antibodies [107]. In dose-increasing studies, intravenous measles virus injection showed efficacy only when the dose reached a high dose of $10^{11}$ TCID50. In mice with transplanted tumors, intravenous injection of reovirus (REV) for 3 weeks after initial inhibition of tumor growth resulted in tumor regeneration, while the serum titer of anti- REVs antibodies increased [108]. Phase I study showed that 12 of 33 patients (36\%) reached the maximum neutralizing REV antibody titer on the 7th day and 20 patients (61\%) reached the maximum neutralizing REV antibody titer on the 14th day [109]. Hence, in the first week of treatment, speediness, repetitive, high-dose administration should be given before serum neutralizing antibodies rise, and should be combined with other anticancer therapies [106].

\section{Increase the efficacy of oHSV deliver to tumor cells}

At present, in the application of ohsv, there are some problems that limit its therapeutic effect, whether intratumoral or intravenous injection, there are some defects. Intratumoral injection can ensure that virus particles reach the lesion directly, but it is difficult to spread to the lesion area outside the injection area. Intravenous injection provides an opportunity for the virus to infect all cancer cells, and is particularly effective in the treatment of metastatic lesions [110]. Nevertheless, viral particles injected into veins are bound to suffer innate immune responses from the host [111], which may result in the virus particles being neutralized by antibodies before reaching the target cells.

The receptors that bind oHSV to cells are repositioned to ensure that the virus is more readily accessible to cancer cells. The co-injection of oHSV and collagenase can degrade the extracellular matrix of tumors by collagenase, and make the region outside the injection site of virus particles diffuse. The method for delivery of the oHSV can be enhanced or reduced by pretreatment with antiangiogenesis molecules. When oHSV was administered by direct injection, prior injection of cyclic RGD peptide, an antiangiogenic agent, reduced tumor vascular permeability and infiltration of leukocytes [112]. When oHSV is injected intravenously, the blood-brain barrier will increase the difficulty of injection. In order to solve this problem, it has been proved that destruction of the blood-brain barrier through hypertonic solution of mannitol can increase the number of viruses reaching tumors [110]. Ultrasound technique is also used to enhance the permeability of cell membrane and the efficacy of chemotherapeutic drugs anti-cancer [113]. Shintani et al. showed that effective use of ultrasound technology to help oHSV-1 enter squamous cell carcinomas [114]. Combination with key immunoregulatory inhibitors can improve the efficacy of oncolytic virus. For example, a study showed that intravenous injection of anti-PD-1 antibodies combined with Reolysin was significantly more effective in treating subcutaneous melanoma in mice than intravenous injection of Reolysin or anti-PD-1 alone [115]. Combination of anti-PD-1 antibody therapy can improve NK cells' effective lysis of REV infected malignant cells by reducing the activity of regulatory T cells. Phase I study of combined therapy of oncolytic virus T-Vec and pembrolizumab (anti-PD-1) for head and neck cancer has been completed [105].

Besides, the oHSV combination with chemotherapy is also an effective strategy for tumor treatment. Toyoizumi et al. showed that combining the HSV1716 with chemotherapeutic drug MMC to treat the human non-small cell lung cancer yielded profound efficacy [116]. This study showed that chemotherapy and oHSV can work together treat cancer, and this synergistic effect will strengthen anti-tumor ability. Co-administrated with cyclophosphamide, the anticancer activity of HrR3 improved effectively [117]. Cyclophosphamide can enhance the replication of oncolytic virus by inhibiting the immune response of the system and has better anti-cancer effect [118]. However, in all oncolytic theatmets, the long range of side effects of inducing via body anti-tumor immunity, such as the emergence of AIDs, requires close study. 


\section{Conclusion}

Oncolytic therapy, successes or failure hangs on the interaction of antiviral and antitumor immune responses between virus and host. HSV has been shown to be a site virus gets for oncolytic treatment because it is susceptible to genetic changes, deletions or mutations in genes with immunoregulatory function like ICP0, ICP 34.5, ICP 27, Us3 and UL39. This genetic alteration may result in an enhanced innate immune response, weakening viral replication and spreading in tumors.

At present, oHSV applied in clinical trials have not experienced serious adverse result and has achieved some effectiveness. For example, HSV1716 has been used for the treatment of oral squamous cell carcinoma and gloma [85-87]; G47 $\Delta$ showed efficacy in glioma, breast cancer [93], malignant peripheral nerve sheath tumor [92], schwannoma [89], nasopharyngeal carcinoma [71], hepatocellular carcinoma [88], prostate cancer [87, 90, 91], colorectal cancer and thyroid carcinoma; NV1020 can effectively control liver metastasis and prolong survival via re-sensitizing to chemotherapy [100].

Although the deleted or mutated genes confer safety and selectivity to oHSV in the treatments of tumor cells, efficacy has been attenuated. Direct injection of oHSVs is usually preferred during treatment, but this procedure limits the delivery to the sites where the tumor actually occurs. Physical factors like the extracellular matrix can limit the initial distribution and external diffusion of oHSV in the tumors [119]. The inborn and acquired anti-virus immunity can limit the replication and spread of oHSV [120]. In oncolytic virotherapy, these are only some examples of the many hurdles to be overcome. This made it necessary to combine oHSV with other therapies. The expectations are to develop a combination therapy regimen that produces synergic action against tumor cells without overlapping side effects. For examples, the combinations of oHSV with collagenase can degrade the extracellular matrix of tumors by collagenase, and make the region outside the injection site of virus particles diffuse; Injection of circulating RGD peptide before oHSV infection can reduce the permeability of blood vessels and infiltration of leukocytes in tumors [112]; and many published combination joint research tested the efficacy of oHSV combined with immunotherapies and chemotherapies in vitro. These identified combinations have achieved some good results.

With the development of preclinical research into clinical application, it is more likely to achieve greater success in understanding the combination of oHSV and other treatments. In a word, there are many areas to be researched in development of oHSV combined with other therapies. But hopefully all would join hand to cure cancer patients.

\section{Abbreviations}

APC: antigen presenting cell; DC: Dendritic cell; DNAM1: DNAX accessory molecule 1; EIF2a: eukaryotic Initiation Factor 2; GM-CSF: granulocyte macrophage colony-stimulating factor; IFN: interferon; OHSV: oncolytic herpes simplex virus; OPTN: optineurin; PKR: protein kinase R; RR: ribonucleotide reductase; TAP: transporter associated with antigen presentation; TK: thymidine kinase; TL: T Iymphocyte; TNF-a: tumor necrosis factor; Vhs: virion host shutoff protein

\section{Acknowledgements}

Not applicable.

\section{Funding}

This work was partially supported by National Key Research and Development Program of China (2018YFD0501600), Shandong province Key Research and Development program Fund (2018GNC113011), National Natural Science Fund of China (31872490, 31672556, 31502064), Taishan Scholar and Distinguished Experts $(\mathrm{H} . \mathrm{H}$.)

\section{Availability of data and materials}

Data sharing is not applicable to this article as no datasets were generated or analysed during the current study.

\section{Authors' contributions}

WQM, HMW and $\mathrm{HBH}$ participated in conception, data collection and data analysis and writing the manuscript; WQM prepared Figs. 1, 2; HMW and $\mathrm{HBH}$ critical review and making revisions. All authors read and approved the manuscript.

Ethics approval and consent to participate

Not applicable.

\section{Consent for publication}

Not applicable.

\section{Competing interests}

The authors declare that they have no competing interests.

\section{Publisher's Note}

Springer Nature remains neutral with regard to jurisdictional claims in published maps and institutional affiliations.

Received: 8 August 2018 Accepted: 6 December 2018

Published online: 18 December 2018

\section{References}

1. Sanchala DS, Bhatt LK, Prabhavalkar KS. Oncolytic Herpes Simplex viral therapy: a stride toward selective targeting of Cancer cells. Front Pharmacol. 2017:8:270.

2. Hamid O, Hoffner B, Gasal E, Hong J, Carvajal RD. Oncolytic immunotherapy: unlocking the potential of viruses to help target cancer. Cancer Immunol Immunother. 2017:66(10):1249-64.

3. Hou P, Wang H, Zhao G, He C, He H. Rapid detection of infectious bovine Rhinotracheitis virus using recombinase polymerase amplification assays. BMC Vet Res. 2017;13(1):386.

4. Dai MH, Zamarin D, Gao SP, Chou TC, Gonzalez L, Lin SF, Fong Y. Synergistic action of oncolytic herpes simplex virus and radiotherapy in pancreatic cancer cell lines. Br J Surg. 2010:97(9):1385-94.

5. Eisenberg DP, Adusumilli PS, Hendershott KJ, Yu Z, Mullerad M, Chan MK, Chou TC, Fong Y. 5-fluorouracil and gemcitabine potentiate the efficacy of oncolytic herpes viral gene therapy in the treatment of pancreatic cancer. J Gastrointest Surg. 2005;9(8):1068-77 discussion 1077-1069.

6. Hartkopf AD, Fehm T, Wallwiener D, Lauer U. Oncolytic virotherapy of gynecologic malignancies. Gynecol Oncol. 2011;120(2):302-10.

7. De Clercq E. Antiviral drugs in current clinical use. J Clin Virol. 2004;30(2): $115-33$

8. Todo T. "Armed" oncolytic herpes simplex viruses for brain tumor therapy. Cell Adhes Migr. 2008;2(3):208-13.

9. Sokolowski NA, Rizos H, Diefenbach RJ. Oncolytic virotherapy using herpes simplex virus: how far have we come? Oncolytic Virother. 2015:4:207-19. 
10. Suazo PA, Ibanez FJ, Retamal-Diaz AR, Paz-Fiblas MV, Bueno SM, Kalergis AM, Gonzalez PA. Evasion of early antiviral responses by herpes simplex viruses. Mediat Inflamm. 2015;2015:593757.

11. Bedoui $\mathrm{S}$, Greyer $\mathrm{M}$. The role of dendritic cells in immunity against primary herpes simplex virus infections. Front Microbiol. 2014;5:533.

12. Rombout JH, Yang G, Kiron V. Adaptive immune responses at mucosal surfaces of teleost fish. Fish Shellfish Immunol. 2014;40(2):634-43.

13. Yu X, He S. The interplay between human herpes simplex virus infection and the apoptosis and necroptosis cell death pathways. Virol J. 2016;13:77.

14. Hook LM, Lubinski JM, Jiang M, Pangburn MK, Friedman HM. Herpes simplex virus type 1 and 2 glycoprotein C prevents complement-mediated neutralization induced by natural immunoglobulin M antibody. J Virol. 2006; 80(8):4038-46.

15. Wang X, Ju Z, Huang J, Hou M, Zhou L, Qi C, Zhang Y, Gao Q, Pan Q, Li G, Zhong J, Wang $C$. The relationship between the variants of the bovine MBL2 gene and milk production traits, mastitis, serum MBL-C levels and complement activity. Vet Immunol Immunopathol. 2012;148(3-4):311-9.

16. Dubin G, Frank I, Friedman HM. Herpes simplex virus type 1 encodes two fc receptors which have different binding characteristics for monomeric immunoglobulin G (lgG) and lgG complexes. J Virol. 1990;64(6):2725-31.

17. Lubinski JM, Lazear HM, Awasthi S, Wang F, Friedman HM. The herpes simplex virus $1 \mathrm{lgG}$ fc receptor blocks antibody-mediated complement activation and antibody-dependent cellular cytotoxicity in vivo. J Virol. 2011; 85(7):3239-49.

18. Grauwet K, Cantoni C, Parodi M, De Maria A, Devriendt B, Pende D, Moretta $L$, Vitale M, Favoreel HW. Modulation of CD112 by the alphaherpesvirus gD protein suppresses DNAM-1-dependent NK cell-mediated lysis of infected cells. Proc Natl Acad Sci U S A. 2014;111(45):16118-23.

19. Yuan W, Dasgupta A, Cresswell P. Herpes simplex virus evades natural killer T cell recognition by suppressing CD1d recycling. Nat Immunol. 2006;7(8):835-42.

20. Su C, Zhan G, Zheng C. Evasion of host antiviral innate immunity by HSV-1, an update. Virol J. 2016;13:38.

21. Peters C, Rabkin SD. Designing Herpes viruses as Oncolytics. Mol Ther Oncolytics. 2015;2:15010.

22. Shan S, Qi C, Zhu Y, Li H, An L, Yang G. Expression profile of carp IFN correlate with the up-regulation of interferon regulatory factor-1 (IRF-1) in vivo and in vitro: the pivotal molecules in antiviral defense. Fish Shellfish Immunol. 2016;52:94-102.

23. Yang Y, Wu S, Wang Y, Pan S, Lan B, Liu Y, Zhang L, Leng Q, Chen D, Zhang C, He B, Cao Y. The Us3 protein of Herpes Simplex virus 1 inhibits T cell signaling by confining linker for activation of T cells (LAT) activation via TRAF6 protein. J Biol Chem. 2015;290(25):15670-8.

24. van Lint AL, Murawski MR, Goodbody RE, Severa M, Fitzgerald KA, Finberg RW, Knipe DM, Kurt-Jones EA. Herpes simplex virus immediate-early ICPO protein inhibits toll-like receptor 2-dependent inflammatory responses and NF-kappaB signaling. J Virol. 2010;84(20):10802-11.

25. Zhang J, Wang S, Wang K, Zheng C. Herpes simplex virus 1 DNA polymerase processivity factor UL42 inhibits TNF-alpha-induced NF-kappaB activation by interacting with p65/RelA and p50/NF-kappaB1. Med Microbiol Immunol. 2013;202(4):313-25.

26. Wang K, Ni L, Wang S, Zheng C. Herpes simplex virus 1 protein kinase US3 hyperphosphorylates p65/RelA and dampens NF-kappaB activation. J Virol. 2014;88(14):7941-51.

27. Kim JC, Lee SY, Kim SY, Kim JK, Kim HJ, Lee HM, Choi MS, Min JS, Kim MJ, Choi HS, Ahn JK. HSV-1 ICP27 suppresses NF-kappaB activity by stabilizing IkappaBalpha. FEBS Lett. 2008;582(16):2371-6.

28. Xing J, Wang S, Lin R, Mossman $\mathrm{KL}$, Zheng C. Herpes simplex virus 1 tegument protein US11 downmodulates the RLR signaling pathway via direct interaction with RIG-I and MDA-5. J Virol. 2012;86(7):3528-40.

29. Zhu YY, Xing WX, Shan SJ, Zhang SQ, Li YQ, Li T, An L, Yang GW. Characterization and immune response expression of the rig-l-like receptor mda5 in common carp Cyprinus carpio. J Fish Biol. 2016;88(6):2188-202.

30. Ma Y, Jin H, Valyi-Nagy T, Cao Y, Yan Z, He B. Inhibition of TANK binding kinase 1 by herpes simplex virus 1 facilitates productive infection. J Virol. 2012;86(4):2188-96.

31. Wang $S$, Wang $K$, Lin $R$, Zheng C. Herpes simplex virus 1 serine/threonine kinase US3 hyperphosphorylates IRF3 and inhibits beta interferon production. J Virol. 2013;87(23):12814-27.

32. Paladino P, Collins SE, Mossman KL. Cellular localization of the herpes simplex virus ICPO protein dictates its ability to block IRF3-mediated innate immune responses. PLoS One. 2010;5(4):e10428.
33. Everett RD. Dynamic response of IFI16 and Promyelocytic leukemia nuclear body components to Herpes Simplex virus 1 infection. J Virol. 2015;90(1): 167-79.

34. Zenner HL, Mauricio R, Banting G, Crump CM. Herpes simplex virus 1 counteracts tetherin restriction via its virion host shutoff activity. J Virol. 2013;87(24):13115-23.

35. Sanchez R, Mohr I. Inhibition of cellular 2'-5' oligoadenylate synthetase by the herpes simplex virus type 1 Us11 protein. J Virol. 2007;81(7):3455-64.

36. Poppers J, Mulvey M, Khoo D, Mohr I. Inhibition of PKR activation by the proline-rich RNA binding domain of the herpes simplex virus type 1 Us11 protein. J Virol. 2000;74(23):11215-21.

37. Johnson KE, Song B, Knipe DM. Role for herpes simplex virus 1 ICP27 in the inhibition of type I interferon signaling. Virology. 2008;374(2):487-94.

38. Kaufman HL, Kohlhapp FJ, Zloza A. Oncolytic viruses: a new class of immunotherapy drugs. Nat Rev Drug Discov. 2015;14(9):642-62.

39. Saha D, Wakimoto H, Rabkin SD. Oncolytic herpes simplex virus interactions with the host immune system. Curr Opin Virol. 2016;21:26-34.

40. Ma Y, He B. Recognition of herpes simplex viruses: toll-like receptors and beyond. J Mol Biol. 2014;426(6):1133-47.

41. Gobeil PA, Leib DA. Herpes simplex virus gamma34.5 interferes with autophagosome maturation and antigen presentation in dendritic cells. MBio. 2012;3(5):e00267-12.

42. Heilingloh CS, Muhl-Zurbes P, Steinkasserer A, Kummer M. Herpes simplex virus type 1 ICP0 induces CD83 degradation in mature dendritic cells independent of its E3 ubiquitin ligase function. J Gen Virol. 2014;95(Pt 6): 1366-75.

43. Pourchet A, Fuhrmann SR, Pilones KA, Demaria S, Frey AB, Mulvey M, Mohr I. CD8(+) T-cell immune evasion enables oncolytic virus immunotherapy. EBioMed. 2016:5:59-67.

44. Neumann J, Eis-Hubinger AM, Koch N. Herpes simplex virus type 1 targets the MHC class II processing pathway for immune evasion. J Immunol. 2003; 171(6):3075-83.

45. Trgovcich J, Johnson D, Roizman B. Cell surface major histocompatibility complex class II proteins are regulated by the products of the gamma(1)34. 5 and $U(L) 41$ genes of herpes simplex virus 1. J Virol. 2002;76(14):6974-86.

46. Sloan DD, Jerome KR. Herpes simplex virus remodels T-cell receptor signaling, resulting in p38-dependent selective synthesis of interleukin-10. J Virol. 2007:81(22):12504-14.

47. Xie W, Zhou J. Aberrant regulation of autophagy in mammalian diseases. Biol Lett. 2018;14(1):20170540.

48. O'Connell D, Liang C. Autophagy interaction with herpes simplex virus type1 infection. Autophagy. 2016;12(3):451-9.

49. Orvedahl A, Alexander D, Talloczy Z, Sun Q, Wei Y, Zhang W, Burns D, Leib DA, Levine B. HSV-1 ICP34.5 confers neurovirulence by targeting the Beclin 1 autophagy protein. Cell Host Microbe. 2007;1(1):23-35.

50. Orvedahl A, Levine B. Autophagy and viral neurovirulence. Cell Microbiol. 2008:10(9):1747-56.

51. Kanai R, Zaupa C, Sgubin D, Antoszczyk SJ, Martuza RL, Wakimoto H, Rabkin SD. Effect of gamma34.5 deletions on oncolytic herpes simplex virus activity in brain tumors. J Virol. 2012;86(8):4420-31.

52. Pilli M, Arko-Mensah J, Ponpuak M, Roberts E, Master S, Mandell MA Dupont N, Ornatowski W, Jiang S, Bradfute SB, Bruun JA, Hansen TE, Johansen T, Deretic V. TBK-1 promotes autophagy-mediated antimicrobial defense by controlling autophagosome maturation. Immunity. 2012;37(2): $223-34$

53. Lussignol M, Queval C, Bernet-Camard MF, Cotte-Laffitte J, Beau I, Codogno P, Esclatine A. The herpes simplex virus 1 Us 11 protein inhibits autophagy through its interaction with the protein kinase PKR. J Virol. 2013;87(2):859-71.

54. You $Y$, Cheng AC, Wang MS, Jia RY, Sun KF, Yang $Q$, Wu Y, Zhu D, Chen $S$, Liu MF, Zhao XX, Chen XY. The suppression of apoptosis by alphaherpesvirus. Cell Death Dis. 2017;8(4):e2749.

55. Cartier A, Broberg E, Komai T, Henriksson M, Masucci MG. The herpes simplex virus-1 Us3 protein kinase blocks CD8T cell lysis by preventing the cleavage of bid by granzyme B. Cell Death Differ. 2003;10(12):1320-8.

56. Jerome KR, Chen Z, Lang R, Torres MR, Hofmeister J, Smith S, Fox R, Froelich CJ, Corey L. HSV and glycoprotein J inhibit caspase activation and apoptosis induced by granzyme B or Fas. J Immunol. 2001;167(7):3928-35.

57. Dufour F, Sasseville AM, Chabaud S, Massie B, Siegel RM, Langelier Y. The ribonucleotide reductase R1 subunits of herpes simplex virus types 1 and 2 protect cells against TNFalpha- and FasL-induced apoptosis by interacting with caspase-8. Apoptosis. 2011;16(3):256-71. 
58. Guo H, Omoto S, Harris PA, Finger JN, Bertin J, Gough PJ, Kaiser WJ, Mocarski ES. Herpes simplex virus suppresses necroptosis in human cells. Cell Host Microbe. 2015;17(2):243-51.

59. Wang X, Li Y, Liu S, Yu X, Li L, Shi C, He W, Li J, Xu L, Hu Z, Yu L, Yang Z, Chen Q, Ge L, Zhang Z, Zhou B, et al. Direct activation of RIP3/MLKLdependent necrosis by herpes simplex virus 1 (HSV-1) protein ICP6 triggers host antiviral defense. Proc Natl Acad Sci U S A. 2014;111(43):15438-43.

60. Martuza RL, Malick A, Markert JM, Ruffner KL, Coen DM. Experimental therapy of human glioma by means of a genetically engineered virus mutant. Science. 1991;252(5007):854-6.

61. Markert JM, Coen DM, Malick A, Mineta T, Martuza RL. Expanded spectrum of viral therapy in the treatment of nervous system tumors. J Neurosurg. 1992;77(4):590-4.

62. Liu S, Dai M, You L, Zhao Y. Advance in herpes simplex viruses for cancer therapy. Sci China Life Sci. 2013;56(4):298-305.

63. D J. GOLDSTEIN. And WELLER. SK. Herpes Simplex virus type 1-induced ribonucleotide reductase activity is dispensable for virus growth and DNA synthesis: isolation and characterization of an ICP6 lacZ insertion mutant. J Virol. 1988;62(1):196-205.

64. Preston GV, Palfreyman WJ, Dutia MB. Identification of a Herpes Simplex virus type 1 polypeptide which is a component of the virus-induced ribonucleotide reductase. J Gen Virol. 1984;65(9):1457 1466.

65. He B, Gross M, Roizman B. The gamma(1)34.5 protein of herpes simplex virus 1 complexes with protein phosphatase 1alpha to dephosphorylate the alpha subunit of the eukaryotic translation initiation factor 2 and preclude the shutoff of protein synthesis by double-stranded RNA-activated protein kinase. Proc Natl Acad Sci U S A. 1997;94(3):843-8.

66. Chou J, Roizman B. The gamma 1(34.5) gene of herpes simplex virus 1 precludes neuroblastoma cells from triggering total shutoff of protein synthesis characteristic of programed cell death in neuronal cells. Proc Natl Acad Sci U S A. 1992;89(8):3266-70.

67. Shirota T, Kasuya H, Kodera Y, Nishikawa Y, Shikano T, Sahin TT, Gewen T, Yamamura K, Fukuda S, Kanzaki A, Yamada S, Fujii T, Sugimoto H, Nomoto S, Takeda S, Nakao A. Oncolytic herpes virus induces effective anti-cancer immunity against murine colon cancer. Hepato-Gastroenterology. 2011; 58(110-111):1482-9.

68. Kanzaki A, Kasuya H, Yamamura K, Sahin T, Nomura N, Shikano T, Shirota T, Tan G, Fukuda S, Misawa M, Nishikawa Y, Yamada S, Fujii T, Sugimoto H, Nomoto S, Takeda S, et al. Antitumor efficacy of oncolytic herpes simplex virus adsorbed onto antigen-specific lymphocytes. Cancer Gene Ther. 2012;19(4):292-8.

69. Koshizuka T, Kawaguchi Y, Nishiyama Y. Herpes simplex virus type 2 membrane protein UL56 associates with the kinesin motor protein KIF1A. J Gen Virol. 2005:86(Pt 3):527-33.

70. Kramm CM, Chase M, Herrlinger U, Jacobs A, Pechan PA, Rainov NG, SenaEsteves M, Aghi M, Barnett FH, Chiocca EA, Breakefield XO. Therapeutic efficiency and safety of a second-generation replication-conditional HSV1 vector for brain tumor gene therapy. Hum Gene Ther. 1997:8(17):2057-68.

71. Wang JN, Hu P, Zeng MS, Liu RB. Anti-tumor effect of oncolytic herpes simplex virus G47delta on human nasopharyngeal carcinoma. Chinese J Cancer. 2011;30(12):831-41.

72. Samoto K, Ehtesham M, Perng GC, Hashizume K, Wechsler SL, Nesburn AB, Black KL, Yu JS. A herpes simplex virus type 1 mutant with gamma 34.5 and LAT deletions effectively oncolyses human U87 glioblastomas in nude mice. Neurosurgery. 2002;50(3):599-605 discussion 605-596.

73. Samoto K, Perng GC, Ehtesham M, Liu Y, Wechsler SL, Nesburn AB, Black KL, YU JS. A herpes simplex virus type 1 mutant deleted for gamma34.5 and LAT kills glioma cells in vitro and is inhibited for in vivo reactivation. Cancer Gene Ther. 2001;8(4):269-77.

74. Liu BL, Robinson M, Han ZQ, Branston RH, English C, Reay P, McGrath Y, Thomas SK, Thornton M, Bullock P, Love CA, Coffin RS. ICP34.5 deleted herpes simplex virus with enhanced oncolytic, immune stimulating, and anti-tumour properties. Gene Ther. 2003;10(4):292-303.

75. Cui LL, Yang G, Pan J, Zhang C. Tumor necrosis factor alpha knockout increases fertility of mice. Theriogenology. 2011;75(5):867-76.

76. Kaufman HL, Kim DW, DeRaffele G, Mitcham J, Coffin RS, Kim-Schulze S. Local and distant immunity induced by intralesional vaccination with an oncolytic herpes virus encoding GM-CSF in patients with stage IIIC and IV melanoma. Ann Surg Oncol. 2010;17(3):718-30.

77. Kirn D, Martuza RL, Zwiebel J. Replication-selective virotherapy for cancer: biological principles, risk management and future directions. Nat Med. 2001; 7(7):781-7.
78. Kanai R, Wakimoto H, Cheema T, Rabkin SD. Oncolytic herpes simplex virus vectors and chemotherapy: are combinatorial strategies more effective for cancer? Future Oncol. 2010;6(4):619-34.

79. Rampling R, Cruickshank G, Papanastassiou V, Nicoll J, Hadley D, Brennan D, Petty R, MacLean A, Harland J, McKie E, Mabbs R, Brown M. Toxicity evaluation of replication-competent herpes simplex virus (ICP 34.5 null mutant 1716) in patients with recurrent malignant glioma. Gene Ther. 2000; 7(10):859-66.

80. Mace AT, Ganly I, Soutar DS, Brown SM. Potential for efficacy of the oncolytic Herpes simplex virus 1716 in patients with oral squamous cell carcinoma. Head Neck. 2008;30(8):1045-51.

81. Papanastassiou V, Rampling R, Fraser M, Petty R, Hadley D, Nicoll J, Harland J, Mabbs R, Brown M. The potential for efficacy of the modified (ICP 34.5(-)) herpes simplex virus HSV1716 following intratumoural injection into human malignant glioma: a proof of principle study. Gene Ther. 2002;9(6):398-406.

82. Harrow S, Papanastassiou V, Harland J, Mabbs R, Petty R, Fraser M, Hadley D, Patterson J, Brown SM, Rampling R. HSV1716 injection into the brain adjacent to tumour following surgical resection of high-grade glioma: safety data and long-term survival. Gene Ther. 2004:11(22):1648-58.

83. Moore AE. Viruses with oncolytic properties and their adaptation to tumors. Ann N Y Acad Sci. 1952;54(6):945-52.

84. Markert JM, Medlock MD, Rabkin SD, Gillespie GY, Todo T, Hunter WD, Palmer CA, Feigenbaum F, Tornatore C, Tufaro F, Martuza RL. Conditionally replicating herpes simplex virus mutant, G207 for the treatment of malignant glioma: results of a phase I trial. Gene Ther. 2000;7(10):867-74.

85. Todo T, Martuza RL, Rabkin SD, Johnson PA. Oncolytic herpes simplex virus vector with enhanced MHC class I presentation and tumor cell killing. Proc Natl Acad Sci U S A. 2001;98(11):6396-401.

86. Passer BJ, Wu CL, Wu S, Rabkin SD, Martuza RL. Analysis of genetically engineered oncolytic herpes simplex viruses in human prostate cancer organotypic cultures. Gene Ther. 2009;16(12):1477-82.

87. Fukuhara H, Martuza RL, Rabkin SD, Ito Y, Todo T. Oncolytic herpes simplex virus vector g47delta in combination with androgen ablation for the treatment of human prostate adenocarcinoma. Clin Cancer Res. 2005;11(21): 7886-90.

88. Wang J, Xu L, Zeng W, Hu P, Zeng M, Rabkin SD, Liu R. Treatment of human hepatocellular carcinoma by the oncolytic herpes simplex virus G47delta. Cancer Cell Int. 2014;14(1):83.

89. Prabhakar S, Messerli SM, Stemmer-Rachamimov AO, Liu TC, Rabkin S, Martuza R, Breakefield XO. Treatment of implantable NF2 schwannoma tumor models with oncolytic herpes simplex virus G47Delta. Cancer Gene Ther. 2007;14(5):460-7

90. Varghese S, Rabkin SD, Liu R, Nielsen PG, Ipe T, Martuza RL. Enhanced therapeutic efficacy of IL-12, but not GM-CSF, expressing oncolytic herpes simplex virus for transgenic mouse derived prostate cancers. Cancer Gene Ther. 2006;13(3):253-65.

91. Fukuhara H, Ino Y, Kuroda T, Martuza RL, Todo T. Triple gene-deleted oncolytic herpes simplex virus vector double-armed with interleukin 18 and soluble B7-1 constructed by bacterial artificial chromosome-mediated system. Cancer Res. 2005;65(23):10663-8.

92. Antoszczyk S, Spyra M, Mautner VF, Kurtz A, Stemmer-Rachamimov AO, Martuza RL, Rabkin SD. Treatment of orthotopic malignant peripheral nerve sheath tumors with oncolytic herpes simplex virus. Neuro-Oncology. 2014; 16(8):1057-66.

93. Liu R, Martuza RL, Rabkin SD. Intracarotid delivery of oncolytic HSV vector G47Delta to metastatic breast cancer in the brain. Gene Ther. 2005;12(8): 647-54.

94. Cheema TA, Wakimoto H, Fecci PE, Ning J, Kuroda T, Jeyaretna DS, Martuza $\mathrm{RL}$, Rabkin SD. Multifaceted oncolytic virus therapy for glioblastoma in an immunocompetent cancer stem cell model. Proc Natl Acad Sci U S A. 2013; 110(29):12006-11

95. McAuliffe PF, Jarnagin WR, Johnson $P$, Delman KA, Federoff $H$, Fong $Y$. Effective treatment of pancreatic tumors with two multimutated herpes simplex oncolytic viruses. J Gastroint Surg. 2000;4(6):580-8.

96. Gutermann A, Mayer E, von Dehn-Rothfelser K, Breidenstein C, Weber M, Muench M, Gungor D, Suehnel J, Moebius U, Lechmann M. Efficacy of oncolytic herpesvirus NV1020 can be enhanced by combination with chemotherapeutics in colon carcinoma cells. Hum Gene Ther. 2006;17(12): 1241-53.

97. Cozzi PJ, Malhotra S, McAuliffe P, Kooby DA, Federoff HJ, Huryk B, Johnson $\mathrm{P}$, Scardino PT, Heston WD, Fong Y. Intravesical oncolytic viral therapy using 
attenuated, replication-competent herpes simplex viruses G207 and Nv1020 is effective in the treatment of bladder cancer in an orthotopic syngeneic model. FASEB J. 2001;15(7):1306-8.

98. Ebright MI, Zager JS, Malhotra S, Delman KA, Weigel TL, Rusch WW, Fong $Y$ Replication-competent herpes virus NV1020 as direct treatment of pleural cancer in a rat model. J Thorac Cardiovasc Surg. 2002;124(1):123-9.

99. Kemeny N, Brown K, Covey A, Kim T, Bhargava A, Brody L, Guilfoyle B, Haag NP, Karrasch M, Glasschroeder B, Knoll A, Getrajdman G, Kowal KJ, Jarnagin WR, Fong Y. Phase I, open-label, dose-escalating study of a genetically engineered herpes simplex virus, NV1020, in subjects with metastatic colorectal carcinoma to the liver. Hum Gene Ther. 2006;17(12):1214-24.

100. Geevarghese SK, Geller DA, de Haan HA, Horer M, Knoll AE, Mescheder A, Nemunaitis J, Reid TR, Sze DY, Tanabe KK, Tawfik H. Phase I/II study of oncolytic herpes simplex virus NV1020 in patients with extensively pretreated refractory colorectal cancer metastatic to the liver. Hum Gene Ther. 2010;21(9):1119-28.

101. McGeoch DJ, Dalrymple MA, Davison AJ, Dolan A, Frame MC, McNab D, Perry $L$, Scott JE, Taylor $P$. The complete DNA sequence of the long unique region in the genome of herpes simplex virus type 1. J Gen Virol. 1988;69(Pt 7):1531-74.

102. van de Laar L, Coffer PJ, Woltman AM. Regulation of dendritic cell development by GM-CSF: molecular control and implications for immune homeostasis and therapy. Blood. 2012;119(15):3383-93.

103. Senzer NN, Kaufman HL, Amatruda T, Nemunaitis M, Reid T, Daniels G, Gonzalez R, Glaspy J, Whitman E, Harrington K, Goldsweig H, Marshall T, Love C, Coffin R, Nemunaitis JJ. Phase II clinical trial of a granulocytemacrophage colony-stimulating factor-encoding, second-generation oncolytic herpesvirus in patients with unresectable metastatic melanoma. J Clin Oncol. 2009;27(34):5763-71.

104. Hu JC, Coffin RS, Davis CJ, Graham NJ, Groves N, Guest PJ, Harrington KJ, James ND, Love CA, McNeish I, Medley LC, Michael A, Nutting CM, Pandha HS, Shorrock CA, Simpson J, et al. A phase I study of OncoVEXGM-CSF, a second-generation oncolytic herpes simplex virus expressing granulocyte macrophage colony-stimulating factor. Clin Cancer Res. 2006;12(22):6737-47.

105. Fukuhara $H$, Ino $Y$, Todo T. Oncolytic virus therapy: a new era of cancer treatment at dawn. Cancer Sci. 2016:107(10):1373-9.

106. Gong J, Sachdev E, Mita AC, Mita MM. Clinical development of reovirus for cancer therapy: An oncolytic virus with immune-mediated antitumor activity. World J Methodol. 2016;6(1):25-42.

107. Russell SJ, Federspiel MJ, Peng KW, Tong C, Dingli D, Morice WG, Lowe V, O'Connor MK, Kyle RA, Leung N, Buadi FK, Rajkumar SV, Gertz MA, Lacy MQ, Dispenzieri A. Remission of disseminated cancer after systemic oncolytic virotherapy. Mayo Clin Proc. 2014;89(7):926-33.

108. Hirasawa K, Nishikawa SG, Norman KL, Coffey MC, Thompson BG, Yoon CS, Waisman DM, Lee PW. Systemic reovirus therapy of metastatic cancer in immune-competent mice. Cancer Res. 2003;63(2):348-53.

109. White CL, Twigger KR, Vidal L, De Bono JS, Coffey M, Heinemann L, Morgan R, Merrick A, Errington F, Vile RG, Melcher AA, Pandha HS, Harrington KJ. Characterization of the adaptive and innate immune response to intravenous oncolytic reovirus (Dearing type 3 ) during a phase I clinical trial. Gene Ther. 2008;15(12):911-20.

110. Simpson GR, Han Z, Liu B, Wang Y, Campbell G, Coffin RS. Combination of a fusogenic glycoprotein, prodrug activation, and oncolytic herpes simplex virus for enhanced local tumor control. Cancer Res. 2006;66(9):4835-42.

111. Yang HT, Zou SS, Zhai LJ, Wang Y, Zhang FM, An LG, Yang GW. Pathogen invasion changes the intestinal microbiota composition and induces innate immune responses in the zebrafish intestine. Fish Shellfish Immunol. 2017; 71:35-42.

112. Mullerad M, Bochner BH, Adusumilli PS, Bhargava A, Kikuchi E, Hui-Ni C, Kattan MW, Chou TC, Fong Y. Herpes simplex virus based gene therapy enhances the efficacy of mitomycin $C$ for the treatment of human bladder transitional cell carcinoma. J Urol. 2005;174(2):741-6.

113. Fechheimer M, Boylan JF, Parker S, Sisken JE, Patel GL, Zimmer SG. Transfection of mammalian cells with plasmid DNA by scrape loading and sonication loading. Proc Natl Acad Sci U S A. 1987;84(23):8463-7.

114. Shintani M, Takahashi G, Hamada M, Okunaga S, Iwai S, Yura Y. Effect of ultrasound on herpes simplex virus infection in cell culture. Virol J. 2011:8:446.

115. Rajani K, Parrish C, Kottke T, Thompson J, Zaidi S, Ilett L, Shim KG, Diaz RM, Pandha H, Harrington K, Coffey M, Melcher A, Vile R. Combination therapy with Reovirus and anti-PD-1 blockade controls tumor growth through innate and adaptive immune responses. Mol Ther. 2016;24(1):166-74.
116. Toyoizumi T, Mick R, Abbas AE, Kang EH, Kaiser LR, Molnar-Kimber KL. Combined therapy with chemotherapeutic agents and herpes simplex virus type 1 ICP34.5 mutant (HSV-1716) in human non-small cell lung cancer. Hum Gene Ther. 1999:10(18):3013-29.

117. Wakimoto H, Fulci G, Tyminski E, Chiocca EA. Altered expression of antiviral cytokine mRNAs associated with cyclophosphamide's enhancement of viral oncolysis. Gene Ther. 2004;11(2):214-23.

118. Ikeda K, Ichikawa T, Wakimoto H, Silver JS, Deisboeck TS, Finkelstein D, GRt H, Louis DN, Bartus RT, Hochberg FH, Chiocca EA. Oncolytic virus therapy of multiple tumors in the brain requires suppression of innate and elicited antiviral responses. Nat Med. 1999;5(8):881-7.

119. Yun CO. Overcoming the extracellular matrix barrier to improve intratumoral spread and therapeutic potential of oncolytic virotherapy. Curr Opin Mol Ther. 2008;10(4):356-61.

120. Fukuhara $\mathrm{H}$, Todo T. Oncolytic herpes simplex virus type 1 and host immune responses. Curr Cancer Drug Targets. 2007;7(2):149-55.
Ready to submit your research? Choose BMC and benefit from:

- fast, convenient online submission

- thorough peer review by experienced researchers in your field

- rapid publication on acceptance

- support for research data, including large and complex data types

- gold Open Access which fosters wider collaboration and increased citations

- maximum visibility for your research: over $100 \mathrm{M}$ website views per year

At BMC, research is always in progress.

Learn more biomedcentral.com/submissions 